UDC 342.9

DOI https://doi.org/10.32849/2663-5313/2021.7.09

Serhii Shkliar,

Doctor of Law, Associate Professor, Leading Researcher, Scientific Institute of Public Law, 2a, H. Kirpy street, Kyiv, Ukraine, postal code 03035, Shkliar_Serhii@ukr.net

ORCID: orcid.org/0000-0003-2351-0161

Shkliar, Serhii (2021). Improvement of administrative and legal regulation of control over compliance with legislation on protection of economic competition: foreign experience. Entrepreneurship, Economy and Law, 7, 56-61.

\title{
IMPROVEMENT OF ADMINISTRATIVE AND LEGAL REGULATION OF CONTROL OVER COMPLIANCE WITH LEGISLATION ON PROTECTION OF ECONOMIC COMPETITION: FOREIGN EXPERIENCE
}

Abstract. The issues of identifying peculiarities, methods and means, as well as the state regulatory framework for economic processes (including relations of economic competition) cannot be considered as an exclusive problem of the national economy and the system of public administration of Ukraine. The issue is global and, as a result, is subject to different solutions in each country. Despite the availability of different approaches and disagreements in the understanding of the role of the state in the administrative and legal regulation of relations of economic competition, there are some common global trends in the construction of systems of protection of economic competition, including the system of control over compliance with legislation on protection of economic competition. The international community and some developed countries of the world have relevant experience in the administrative and legal regulation of specificities of control over compliance with legislation on protection of economic competition, the advanced and progressive ideas of which should be taken into account by Ukraine for successful implementation of domestic policy measures in this sphere. The purpose of the article is to make proposals for improving administrative and legal regulation of control over compliance with the legislation on protection of economic competition taking into account the experience of foreign countries. Results. The article proves that the study of the foreign experience of administrative and legal regulation of control over compliance with the legislation on protection of economic competition. The progressive trends of the administrative and legal regulation of control over compliance with the legislation on the protection of economic competition in France, the United States of America and Germany are considered. Conclusions. The positive features of the domestic administrative and legal regulation of control in this field are underlined, and some features are compared with the above-stated countries. The author highlights the principles of foreign experience in the organization of the administrative regulatory mechanism for control over compliance with legislation on protection of economic competition, which should be adopted in Ukraine.

Key words: protection of economic competition, foreign experience, unfair competition, consumer rights protection, responsibility, monopoly, fight against corruption.

\section{Introduction}

The issues of identifying peculiarities, methods and means, as well as the state regulatory framework for economic processes (including relations of economic competition) cannot be considered as an exclusive problem of the national economy and the system of public administration of Ukraine. The issue is global and, as a result, is subject to different solutions in each country.

Despite the availability of different approaches and disagreements in the understanding of the role of the state in the administrative and legal regulation of relations of eco- nomic competition, in there are some common global trends in the construction of systems of protection of economic competition, including the system of control over compliance with legislation on protection of economic competition. The international community and some developed countries of the world have relevant experience in administrative and legal regulation of peculiarities of control over compliance with legislation on protection of economic competition, the advanced and progressive ideas of which should be taken into account by Ukraine for successful implementation of domestic policy measures in this sphere. 
Analysis of recent research and publications. The development of ways and methods of improving administrative and legal regulation of control over compliance with the legislation on protection of economic competition is covered by the contributions of the following scientists: O.M. Vinnyk, O.O. Bakalinska, O.V. Bezukh, V.E. Belianevych, V.V. Bordeniuk, V.P. Dakhno, O.I. Zavada, V.K. Mamutov, O.I. Melnychenko, O.O. Pletnova, N.O. Saniakhmetova, V.S. Shcherbyna and others.

\section{Previously unresolved problems.} Nowadays, there is a lack of studies of administrative and legal regulation of control over compliance with legislation on protection of economic competition taking into account experience of foreign countries.

The purpose of the article is to form proposals for improving administrative and legal regulation of control over compliance with the legislation on protection of economic competition taking into account the experience of foreign countries.

Main material statement. First of all, attention should be paid to the standpoint by B.V. Derevianko and S.A. Parashchuk, who differentiate 4 trends of the formation of legislation on protection against unfair competition. Countries with the legislation of the first trend are countries where the prosecution of unfair competition is based on the general provisions of Civil Tort Law. France, Italy and the Netherlands are among such countries. In general, France is considered the historical homeland of the concept "unfair competition" (Parashchuk, 2002, 5-6). The notion of unfair competition was fixed in the Paris Convention for the Protection of Industrial Property of March 20, 1883 (RT II 1994, 4/5, 19) (hereinafter the Paris Convention) (Paris Convention for the Protection of Industrial Property, 1990). Countries with the legislation of the second trend are countries in which protection against unfair competition is carried using both general provisions of civil law and provisions of special, economic or trade, legislation. Such countries include Great Britain, Ireland, Belgium. The countries of the third trend of legislation are countries that have adopted special (economic or trade) legislation regulating protection against unfair competition. They include Germany, Austria, Switzerland, Spain. In some countries of the fourth trend of legislation against unfair competition, such as the United States, Japan, Canada, regulatory mechanisms against unfair competition are part of anti-trust legislation, as unfair competition is seen as one of the elements of monopoly.
Within the framework of the legislation on combating monopoly, specific elements of offenses characterized as unfair competition (Parashchuk, 2002; Derevianko, 2014) are identified.

\section{United States of America}

The world practice of competition regulation was launched in 1890, when the Sherman Antitrust Act was adopted in the USA. The Sherman Act provided that the trusts that monopolized industry markets should be replaced with decentralized, managed, competing enterprises. This Act prohibited monopolization of any trade sector and provided for a list of penalties that could be applied to monopolists, from monetary fines to criminal liability. In particular, paragraph 1: Every contract, combination in the form of trust or otherwise, or conspiracy, in restraint of trade or commerce among the several States, or with foreign nations, is declared to be illegal. Paragraph 2: Every person who shall monopolize, or attempt to monopolize, or combine or conspire with any other person or persons, to monopolize any part of the trade or commerce among the several States, or with foreign nations, shall be deemed guilty of a felony, and, on conviction thereof (Kolisnychenko, 2004, pp. 74-75). According to the Sherman Act, both the Ministry of Justice and the parties affected by the commerce monopolies could sue them. Firms, deemed guilty of a felony, could be liquidated by the decision of the court; also, court orders prohibiting those types of activities that were considered illegal by the Act could be issued. However, the first court interpretations of the Sherman Act revealed serious doubts about its effectiveness, as it became clear that it was necessary to formulate more precise anti-trust moods of the government. Even basic concepts such as "trust", "monopolization or monopolization attempt", "monopolistic union", "trade restriction" were not defined. This Act was not perfect. Given this, in 1914, the U.S. Congress adopted the Clayton Act and the Federal Trade Commission Act. The first of them banned price discrimination, that is, to discriminate in price between different purchasers, provided that the differences in prices are not caused by different costs; the other one envisaged the creation of a commission for implementation. The following paragraphs of the Clayton Act were called to strengthen and clarify the meaning of the Sherman Act: Paragraph 2 states illegality of price discrimination of purchasers when such discrimination is not due to the difference in costs. Paragraph 3 prohibits exclusive (or "forced") agreements, under which the manufacturer would sell some 
goods to the purchaser only on the condition that the latter purchases other commodities of the same seller, and not of its competitors. Paragraph 7 prohibits the acquisition by one corporation of stock of another if this may weaken competition. Paragraph 8 prohibits the formation of the Board of Directors when the head of one firm is also a member of the board of a competing firm - in large corporations, where the result would be a decrease in competition (Semiuelson, Nordhauz, 1998, p. 271).

In 1936, this Act was supplemented by the Robinson-Patman Act, which prohibited purchasers to agree to pre-discrimination prices. In 1950, the Congress additionally adopted the Celler-Kefauver Act which prohibited the acquisition of shares or property of another firm with negative consequences for "any commercial line". As a result, all horizontal and vertical mergers and mergers of conglomerates were subject to antitrust laws. U.S. antitrust laws also provided for certain exceptions to the application. Thus, the Sherman and Clayton Acts did not apply to trade unions' activities in the field of strike, to farm cooperatives in case of their sale of agricultural products, etc. All of these acts regulate competition in the US for almost 100 years, still being in force (Kolisnychenko, 2004, pp. 74-75).

Modern antitrust laws are implemented by specially established bodies, in particular, in the USA - theFederal TradeCommission (created on the basis of the Federal Trade Commission Act of 1914) and the Antitrust Department of Justice. The main objective of the antitrust laws is to restrict monopolies and their power, to create a competitive environment, and to support small businesses. The strictest antimonopoly Law controls the associations of enterprises that produce similar goods and services, which leads to monopolization of the industry. The methods of implementation of antitrust laws in the USA are liquidation of the firm, it happens for monopolization of more than $60 \%$ of any goods or services, as well as high taxation of monopoly profits, control of prices of monopolists, their disaggregation, etc. (Mochernyi, Usatenko, Chebotar, 2001, p. 150). U.S. antitrust laws are more stringent than those in other countries and are broader in scope. In fact, it does not clearly interpret what is allowed and what is not, creating only a basis for broad powers of the Department of Justice, the Federal Trade Commission and courts to interpret them and apply them in practice (Pindaik, Rubinfeld, 1996, p. 330).

Therefore, it should be noted that the indisputable attainment of the United States legal system is the launching of anti- monopoly and laws on control over compliance with the legislation on protection of economic competition. The positive point is that the legislation has recognized and established that any actions aimed at distortion or violation of economic competition in the market are not only a manifestation of the peculiarities of market competition and deviation in the development of perfect competition, but also a serious violation of market laws, fair trade habits, that is why they are prohibited by law, and society is protected from such violations by force of Statecompulsion. Furthermore, it is essential to mark that the U.S. antitrust laws have established an institution similar to the functions and tasks of the Antimonopoly Committee of Ukraine the Federal Trade Commission, which means common systems and approaches to controlling the protection of economic competition in both States. However, the author notes that other peculiarities of U.S. legislation on protection of economic competition are different from the legislation of Ukraine. In particular, too strict measures and actions of responsibility for violation of legislation on protection of economic competition, providing opportunities for expanded interpretation of antitrust legislation by judicial bodies, as well as control bodies. Such specificities cannot be adopted and adapted in the legislation of Ukraine in view of the national legal system and legal consciousness, which define the necessity of clear and detailed formulation of the articles' dispositions, unambiguous understanding of the regulatory legal provisions.

\section{Federal Republic of Germany}

The Federal Republic of Germany is one of those countries where the legislation on combating unfair competition, in particular, illegal use of business reputation is developed separately from other legal regulations. In the Federal Republic of Germany, an independent antimonopoly (cartel) law arose only in the second half of the 20th century with the adoption of the Law on cartels of 1957. German lawyers distinguish antimonopoly legislation aimed at restricting free competition through cartels or coordinated actions by competitors, and legislation that prevents unfair competition. It appeared much earlier than the antitrust law (the Act Against Unfair Competition of 1909) and protects fair competition between entrepreneurs. Both branches of legislation (antimonopoly law and law against unfair competition law) are defined in the Federal Republic of Germany in one term - "competition law". On June 8, 2004 the German Act against Unfair Competition came into force (Finger, 2019). The special feature of the new Act is that the definition 
of fundamental terms used in the Act is contained in the Civil Code of the Federal Republic of Germany (Bürgerliches Gesetzbuch, BGB). Instead of the "Gute Sitten" concept, the new law uses the notion of "injustice" in accordance with EU legislation. According to the new Act, misleading advertising is prohibited ( $\$ 5$ UWG), comparative advertising is regulated ( $\$ 6 \mathrm{UWG})$. One of the main violations in the Federal Republic of Germany is the attack on business reputation. It is unfair and is expressed in a dismissive attitude or defamation of goods, services, actions or commercial circumstances of a competitor. Clause 4(8) UWG prohibits the statement or dissemination of facts about the goods, services or business of a competitor, which can cause harm to the business or the owner (Finger, 2019; Derevianko, 2014).

The emphasis not only on combating violations of economic competition, but also on preventing such violations is a rather progressive and worthy of following specificity of legislation of the Federal Republic of Germany on protection of economic competition. It should be noted that in comparison with Ukrainian legislation in the field of protection of economic competition, the legislation of Germany focuses more on description in detail of those actions of economic entities, which are qualified as unfair competition, as well as protection of business reputation on the market. Therefore, the legislation of Ukraine in this field needs to be reviewed and clarified in view of similar trends in German legislation.

\section{Conclusions}

Summarizing the above-mentioned experience of foreign countries with developed economies in terms of the introduction and development of their national systems of control over compliance with legislation on protection of economic competition, it is worth stating that in general, Ukrainian legislation on control over compliance with the legislation on protection of economic competition, as compared to the legislation of foreign countries under study, is rather progressive, reflects and strengthens similar principles and fundamentals of the world community in the field of protection of economic competition (prohibition or limitation of monopoly, prohibition of anti-competitive coordinated actions, regulation and control of concentration of economic entities, regulation of prices in sectors of natural monopolies, etc.). It should also be noted that the role of the judiciary in the implementation of the policy of control over compliance with the legislation on protection of economic competition (France, the USA and other countries), which in this field not only apply legal provisions and bring offenders to justice but also officially interpret the laws on protection of economic competition, providing for the establishment of a common practice of legal understanding and application in this field. In the auhtor's opinion, radical methods and measures to control compliance with the legislation on protection of economic competition developed and operating in the USA are not relevant for application in Ukraine. The experience of administrative and legal regulation of control over compliance with legislation on protection of economic competition of the countries of Europe is more appropriate to Ukrainian system of law and the form of government, because the monopoly is not prohibited but regulated in its manifestations in order to prevent infringement of rights of other economic entities, consumers, other participants of market relations. However, administrative and legal regulation of the control over compliance with the legislation on protection of economic competition in Ukraine is similar to the U.S. legal regulatory framework in the context that, in both states, control over compliance with the legislation on protection of economic competition develops as a separate branch of the legal regulatory mechanism, violations of the legislation on protection of economic competition are separate elements of offenses subject to criminal, administrative and other liability.

Despite the sufficient advancement of administrative and legal regulation of control over compliance with the legislation on protection of economic competition in Ukraine, some progressive ideas of international experience of the regulatory framework in this field should be taken into account:

- Fight against corruption. The mentioned experience is the most relevant to control over compliance with legislation on protection of economic competition in public procurement, as well as during the control over compliance with the legislation on protection of economic competition by the bodies of the Antimonopoly Committee of Ukraine, overcoming possible cases of unequal and subjective approach to the participants of the case on violation of the legislation on protection of economic competition;

- Enhancement of liability for violation of legislation on protection against unfair competition and improvement of the administrative and legal regulatory mechanism in this field should be realized through the means of a more precise formulation of dispositions of articles and, accordingly, of elements of offenses;

- Opportunities for effective implementation of the powers of the Antimonopoly Committee of Ukraine concerning market research, 
determination of limits of the commodity market, as well as the status, including monopoly (dominant), of economic entities on this market and to make, as a result of such monitoring, appropriate decisions (orders);

Protection of consumer rights in the field of protection of economic competition by introducing additional violations to the list of violations of the legislation on protection of economic competition: any violation of the right of the consumer to freedom of choice of products during the sale of the products; violation of freedom of the will and/or freedom of expression of the consumer in any way during the sale of the products; the price of products determined in an improper manner.

\section{References:}

Derevianko, B.V. (2014). Shchodo tendentsii formuvannia zakonodavstva pro zakhyst vid nedobrosovisnoi konkurentsii [Regarding the trends in the formation of legislation on protection against unfair competition]. Pravo i suspilstvo - Law and society, no. 3, pp. 103-109 (in Ukrainian).

Finger, M., Schmieder, S. (2019). The New Law Against Unfair Competition: An Assessment Retrieved from: https://www.cambridge.org/core/journals/german-law-journal/article/new-law-againstunfair-competition-an-assessment/9BFE391BC16B30506BA7C0353B4FA5C3 (in English).

Kolisnychenko, I.O. (2004). Svitovyi dosvid derzhavnoho rehuliuvannia konkurentnykh vidnosyn ta obmezhennia monopolizmu [World experience of state regulation of competitive relations and restriction of monopoly]. Problemy ratsionalnoho vykorystannia sotsialno-ekonomichnoho ta pryrodno-resursnoho potentsialu rehionu - Problems of rational use of socio-economic and natural resource potential of the region, no. 1-2, pp. 155-163 (in Ukrainian).

Mochernyi, S.V., Usatenko, O.A., Chebotar, S.I. (2001). Osnovy pidpryiemnytskoi diialnosti [Basics of entrepreneurial activity]. Kyiv: Vydavnychyi tsentr "Akademiia" (in Ukrainian).

Parashchuk, S.A. (2002). Konkurentnoe pravo (pravovoe regulirovanie konkurentcii imonopolii) [Competition law (legal regulation of competition and monopoly)]. Moscow: Gorodetc (in Russian).

Paryzka konventsiia pro okhoronu promyslovoi vlasnosti vid 20 bereznia 1883 roku [Paris Convention for the Protection of Industrial Property from March 20 1883]. (1990). Zibrannia chynnykh mizhnarodnykh dohovoriv Ukrainy - Collection of current international agreements of Ukraine, no. 1 (in Ukrainian).

Pindaik, R.S., Rubinfeld, D.L. (1996). Mikroekonomika [Microeconomics]. Kyiv: Osnovy (in Ukrainian).

Semiuelson, P.A., Nordhauz, V.D. (1998). Mikroekonomika [Microeconomics] / transl. From English S. Panchyshyna. Kyiv: Osnovy (in Ukrainian).

\section{Сергій Шкляр,}

доктор юридичних наук, дочент, провідний науковий співробітник, Науково-дослідний інститут публічного права, вулиия Г. Кірпи, 2a, Київ, Украӥна, індекс 03035, Shkliar_Serhii@ukr.net

ORCID: orcid.org/0000-0003-2351-0161

\section{УДОСКОНАЛЕННЯ АДМІНІСТРАТИВНО-ПРАВОВОГО РЕГУЛЮВАННЯ КОНТРОЛЮ ЗА ДОДЕРЖАННЯМ ЗАКОНОДАВСТВА ПРО ЗАХИСТ ЕКОНОМІЧНОЇ КОНКУРЕНЦІї: ДОСВІД ЗАРУБІЖНИХ КРАЇН}

Анотація. Проблема визначення особливостей, методів і засобів, а також меж державного регулювання економічних процесів не може бути віднесена виключно до проблем національної економіки й системи публічного адміністрування України. Зазначене питання має глобальний, загальносвітовий характер та, як наслідок, підлягає вирішенню в кожній країні по-різному. Попри існування різних підходів і розбіжностей у розумінні ролі держави в адміністративно-правовому регулюванні відносин економічної конкуренції, у світі є окремі спільні тенденції в побудові системи захисту економічної конкуренції, зокрема й системи контролю за дотриманням законодавства про захист економічної конкуренції. Міжнародна спільнота та окремі розвинені держави світу виробили відповідний досвід адміністративно-правового регулювання особливостей контролю за дотриманням законодавства про захист економічної конкуренції, передові та прогресивні ідеї якого повинна врахувати й Україна для успішного проведення заходів внутрішньої політики в досліджуваній сфері. Метою статmi є формування пропозицій щодо вдосконалення адміністративно-правового регулювання контролю за додержанням законодавства про захист економічної конкуренції з урахуванням досвіду зарубіжних країн. Результати. У статті обгрунтовано необхідність вивчення досвіду зарубіжних країн у сфері адміністративно-правового регулювання контролю за додержанням законодавства про захист економічної конкуренції. Розглянуто прогресивні тенденції здійснення адміністративно-правового регулювання контролю за додержанням законодавства про захист економічної конкуренції таких країн, як Франція, Сполучені Штати Америки та Німеччина. 
ADMINISTRATIVE LAW AND PROCESS

Висновки. Визначено позитивні риси вітчизняного нормативно-правового регулювання контролю в досліджуваній сфері, порівняно окремі його особливості зі станом розв’язання зазначеного питання в наведених вище країнах. Автором окреслено засади зарубіжного досвіду організації адміністративно-правового регулювання контролю за додержанням законодавства про захист економічної конкуренції, які варто перейняти Україні, та запропоновано шляхи їх запозичення.

Ключові слова: захист економічної конкуренції, зарубіжний досвід, недобросовісна конкуренція, захист прав споживачів, відповідальність, монополія, боротьба з корупцією.

The article was submitted 15.07.2021

The article was revised 05.08.2021

The article was accepted 23.08.2021 